\title{
Isolated and Interconnected Multi-Area Hybrid Power Systems: A Review on Control Strategies
}

\author{
Sudhanshu Ranjan ${ }^{1}$, Smriti Jaiswal ${ }^{1}{ }^{\mathbb{D}}$, Abdul Latif ${ }^{1, *}$, Dulal Chandra Das ${ }^{1}{ }^{\mathbb{D}}$, Nidul Sinha ${ }^{1}$, \\ S. M. Suhail Hussain ${ }^{2,+}$ (D) and Taha Selim Ustun ${ }^{2}$ (D) \\ 1 Department of Electrical Engineering, National Institute of Technology Silchar, Silchar 788010, Assam, India; \\ ranjan4c@gmail.com (S.R.); smriti_rs@ee.nits.ac.in (S.J.); dulal@ee.nits.ac.in (D.C.D.); \\ nidulsinha@nits.ac.in (N.S.) \\ 2 Fukushima Renewable Energy Institute, National Institute of Advanced Science and Technology (AIST), \\ Koriyama 963-0215, Japan; suhail@ieee.org (S.M.S.H.); selim.ustun@aist.go.jp (T.S.U.) \\ * Correspondence: abdul_rs@ee.nits.ac.in; Tel.: +91-99572-99427 \\ + Current address: Department of Computer Science, National University of Singapore (NUS), \\ Singapore 119077, Singapore.
}

Citation: Ranjan, S.; Jaiswal, S.; Latif, A.; Das, D.C.; Sinha, N.; Hussain, S.M.S.; Ustun, T.S. Isolated and Interconnected Multi-Area Hybrid Power Systems: A Review on Control Strategies. Energies 2021, 14, 8276. https://doi.org/10.3390/ en14248276

Academic Editor: Branislav Hredzak

Received: 4 October 2021

Accepted: 29 November 2021

Published: 8 December 2021

Publisher's Note: MDPI stays neutral with regard to jurisdictional claims in published maps and institutional affiliations.

Copyright: (c) 2021 by the authors. Licensee MDPI, Basel, Switzerland. This article is an open access article distributed under the terms and conditions of the Creative Commons Attribution (CC BY) license (https:// creativecommons.org/licenses/by/ $4.0 /)$.

\begin{abstract}
Concerned with the increasing greenhouse gases in the atmosphere due to fossil fuels, the entire world is focusing on electricity generation through renewable energy resources. The most advantageous aspect of the distributed renewable sources is to provide the electricity to remote, scattered and the deprived rural areas by developing the hybrid power system at the smaller scale where power transmission through grid extension is not viable due to some economical, technical or environmental constraints for building new transmission lines. An accurate and adequate control strategy becomes inevitable to uphold the smooth operation by restraining the frequency and voltage deviation within its limit ensuring the highest degree of reliability of hybrid power system to provide an adequate power quality. In this paper, a comprehensive review of different control strategies adopted in isolated and interconnected multi-area hybrid power systems is presented.
\end{abstract}

Keywords: hybrid power system (HPS); renewable energy; energy storage devices; controllers

\section{Introduction}

Electricity requirement at every inch of our life is indispensable whereas the consequences of using conventional sources of electricity are catastrophic. At the same time, the entire world is running out of available conventional energy resources at a very fast pace. The whole of mankind is trapped in the havoc of nature to enhance the living standard of every individual. Despite it, a significant chunk of the population across the world is deprived of electricity. It's really unfortunate that roughly 1.2 billion people worldwide did not have access to electricity in 2010 and the number has reduced from nearly 860 million in 2018 to 770 million in 2019 [1]. Despite this, the COVID-19 epidemic has reversed previous advances to 750 million in 2020. It has been estimated that by 2030, about 650 million people will be without power due to inadequate substantial and sustained growth in the energy sector [1]. Therefore, to maintain a balance between the development of society and the sustainability of upcoming lives, long-lasting substitutes are essential, and $\mathrm{CO}_{2}{ }^{-}$and pollution-free solutions are required at best $[2,3]$.

The dearth of conventional energy resources and global warming lead the entire world towards harnessing other abundant available energy resources like solar, wind, geothermal, and many more. Since the last few decades, solar PV, solar thermal, and wind energy technologies have been highly encouraged and accepted worldwide to supply power to remote locations and save the environment. The term hybrid power system (HPS) refers to renewable energy with multiple types of generators, usually conventional diesel generators (DG), and renewable energy sources such as photovoltaic (PV), wind 
power. Hybrid power systems may be utilized in grid-connected mode, grid-isolated mode, and particular aims. These energy technologies are also helping tremendously to mitigate the problems associated with conventional energy sources as these sources are almost pollution-free. Nevertheless, climatic dependency of these technologies bottlenecks their use independently as a source of continuous electricity. This is because frequency deviations can increase due to production fluctuations and changes in demand. Therefore, to avoid issues that can affect the security and stability of the power system, intermittent Renewable Energy Sources (RES) power is used as a specific percentage of the system load compared to the interconnected power system. Sometimes these technologies are combined to put forward the hybrid power system (HPS) $[4,5]$ to supply electricity to the areas not connected to the conventional grid. An isolated hybrid power system is a combination of energy storage systems with integrated variable RES. Such a system has little reliance on traditional units and can be used as a practical backup system for providing ancillary system services subjected to techno-economic constraints and reliability requirements [6]. An isolated HPS is generally set up near the load, which reduces the cost invested in transmission and distribution system meanwhile it increases a great degree of usability of the available renewable energy source. The multiple isolated HPS integrated to form an interconnected HPS, which aims to facilitate synergistic development, improve reliability, become resilient to disturbance, and provide direct access to the prosumers. The concept of optimization that leads to improved operational efficiency and profitability of multi-area interconnected HPS has gradually developed into a research hotspot [7].

HPS is permeating across the world rapidly to harness the free and abundant renewable energy at best which is of the utmost essential. Still, these sources are climate dependent, from which arises some challenges like fluctuation in the power generation, voltage deviation, and frequency oscillation. Frequency and voltage deviation beyond its permissible range jeopardize the system performances like the malfunctioning of the measuring devices, insulation failure of the appliances, unscheduled relay tripping, and consequently, the load disconnections and outages of the generation. Interconnection of the HPS with multiple sources improves the reliability of the power supply by complementing each other to a certain extent, hence attracting research attention worldwide. On the contrary, these advantages are ascertained with some critical challenges like system instability due to uncertainties such as wind velocity and solar irradiances which are entirely climate dependent. This natural change in the sources and continuously varying load creates a gap between generation and demand, leading to an active and reactive power mismatch. The critical factors, which impact the reverse active power flow, and the wind energy curtailment in the case of active distribution networks, are an active power mismatch which results in rotor oscillation which may lead to generation outages, undesirable operations of protective devices, and at the worst, total system collapse in the traditional system, have always been the research interests. A centralized control system acts as a part of ancillary services in HPS such that the control variables are the curtailment factor for the active power of PVs which encounter the major issues like increases of demand density and Electric Vehicles (EVs) penetration with time, on sizing a Battery Swapping Station (BSS) and the impact of reverse active power flow [8,9]. In addition, Reactive power mismatch results in voltage deviations which may lead to insulation failure and voltage collapse. Therefore, it is of the utmost importance to keep the deviations within reasonable limits for the reliability of the erected power system. Power quality is also essential to be maintained by ensuring non-violation of the mechanical, electrical, environmental, and economical constraints. A nonlinear model is further derived to analyze voltage and reactive power control applications considering power systems' transient and steady-state behavior. Such investigations are carried out along with bidirectional or reverse active-reactive optimal power flow employing a sensitivity analysis in active distribution networks embedded with subsystems like DG units and BSSs in interconnected HPS [10].

Any conventional power plant whose system inertia is appreciable may be controlled and stabilized by controlling frequency and voltage deviations separately, because the 
change in frequency hardly affects the system voltage and change in voltage hardly affects the system frequency; but a small and medium-scale renewable energy-based power plant behaves differently. Here, both frequency and voltage are affected due to changes in any one of them. Therefore, simultaneous control of voltage and frequency becomes a rudimentary requirement to achieve quality power without interruptions in the power supply. To address the Grid Scheduled Blackouts (GSB) problem, a comprehensive model for a home PV-battery system using economic model predictive control-based strategies is preferred over complex mixed integer nonlinear programming problems. It is also accountable to the battery bank's charging state and lifetime to guarantee energy availability to cover the demand during blackout scenarios in the case of an interconnected HPS switched to islanded mode [11,12].

In this article, a literature review of HPSs in the presence of renewable energy units has been presented and appropriate control strategies have been suggested.

The rest of the paper is organized as follows. Section 2 covers a brief literature review on the components of HPSs technology covering energy-storing components, fast-acting devices, and plug-in electric vehicles. Section 3 projects the challenges of intermittency of RES and its available solutions in HPS. Section 4 presents energy management and demand response strategies in HPS. Section 5 presents a review of different controllers used in HPS. Finally, Sections 6 and 7 present the future research directions and conclusions, respectively.

\section{Literature Review on Components of HPS}

The usability of renewable resources may lead us to enjoy an almost pollution free environment. However, the natural atmospheric change affects the power quality of HPS in terms of voltage and frequency deviations. The most desirable concern about the HPS is to extract the energy of good quality at low cost and to supply to the customers efficiently and reliably. Therefore, maintaining frequency and voltage oscillations within the practical and reasonable limits is inevitable to supply quality power with the help of these sources.

A great deal of work has been previously reported to enhance the efficiency and to improve the quality of HPS comprising different renewable energy sources [13-33]. A lot of research works are going on across the world to look for a new HPS technology for the last two decades [15-18]. A number of studies have given importance to the physical structure of the renewable power plant and its mathematical modeling [19-37]. Such a case of isolated wind energy based HPS that relies on the relationships between the wind station size (WS)/location, variable reverse power flow (VRPF), and demand level is investigated with the constraint of the maximum feasible WS size and VRPF under zero, and are discussed for the active-reactive optimal power flow in the different demand scenarios to ensure energy losses [34,35].

After the erection of the HPS, proper controlling strategies are required to transfer the electrical power, which has been illustrated in some of the literature [38-42]. These controlling schemes are related to the deviation in frequency and voltage. Initially, the HPS had been erected based on a wind turbine system considering diesel generators as a backup source because the potential of the wind energy system was significant [43-58].

Gradually, other renewable energy sources became part of HPS due to technological advancement and reduced cost of electricity generated by non-conventional energy sources. The installation of more complicated and networked devices for monitoring, communication, and control characterizes the digitalization trend. Adequate planning, flexible operations, and technology concerning controls, protection, cyber-physical dependencies, black start, resilience frameworks, markets, forecasting, and capacity expansion models are some significant gaps in areas of research that will aid in addressing these developments in an interlinked manner [59].

A brief literature review covering the significance and applicability of major components which are employed in HPS is covered in the next four subsections in this paper. These subsections include (a) Solar thermal renewable generating units, (b) Energy storing components, (c) Fast energy acting energy devices, and (d) Plug-in-Electric Vehicles (PEVs). 
The distribution of literature with the review of 162 papers listing all the major components employed in HPS is given below in Figure 1. Table 1 lists HPS references reported in literature according to the components.

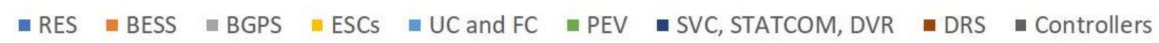

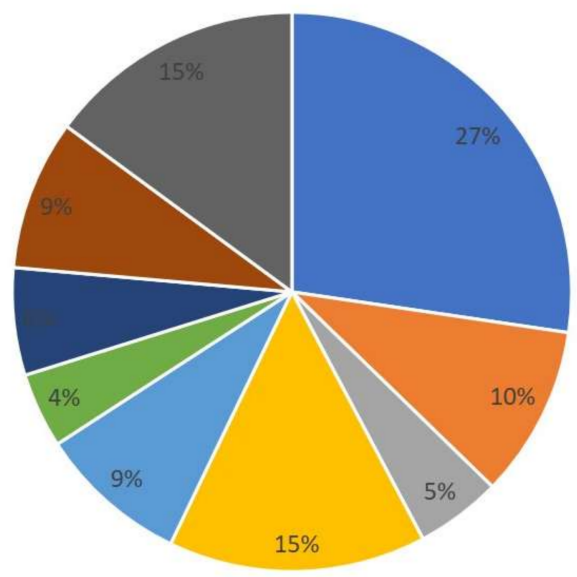

Figure 1. The overall distribution of literature as per components of HPS.

Table 1. Components of HPS reported in the literature.

\begin{tabular}{cc}
\hline References & Components of HPS \\
\hline$[3-5,14,16-18,20-22,25-31,39,44,45,47,49-79]$ & RES \\
{$[14,80-84]$} & SMES \\
{$[20,21,45,47,52,53,57,62,63,70,73,75,76,79,83,85-88]$} & ESCs \\
{$[5,17-21,25,31,45,47,61,66,71-85,88]$} & BESS \\
{$[22,27,39,44,50,66,69-71,77,78,86]$} & UC and FC \\
{$[14,79-83,89-95]$} & PEV \\
{$[96-103]$} & DSP \\
{$[104-120]$} & SVC, STATCOM, DVR \\
{$[45,48,50,54,56,58,73,74,79,110,115,116,121-130]$} & Controllers \\
{$[64,131-145]$} & BGPS \\
\hline
\end{tabular}

\subsection{Solar Thermal Renewable Generating Units in HPS}

Nowadays, renewable sources like wind, PV solar power, solar thermal power, geothermal, and many more are playing a vital role in supplying power to distant locations as well as mainstream areas $[16,17,27,28,39,45,47,49-58]$. From all renewable energy sources, solar thermal power is exceptionally facilitating and commonly deployed. Parabolic trough solar collector (PTC) is one of the most mature and tested solar thermal technologies with a substantial contribution possibility in the energy sector [59]. Spain is leading the way in combined solar thermal power with an installed capacity of $2370 \mathrm{MW}$, surpassed by the USA with a capacity of 1836 MW. In Spain, each plant (50 MW) supplies electricity to up to 2 million people and decreases $\mathrm{CO}_{2}$ emissions by about 149 thousand tons a year relative to coal-fired power production, while in Solana, it provides enough electricity to about 71 thousand households and saves the environment from 42.7 thousand tons of carbon emission per year [60]. The application of Sewage Treatment Plant (STPS) with other sources as a HPS is essential in some of the following countries: Spain with biomass and Concentrated solar power (CSP) generation of $22.5 \mathrm{MW}$, South Africa with $271 \mathrm{MW}$ of PV and CSP, USA with 76 MW of geothermal, PV and CSP, and Chile with $210 \mathrm{MW}$ of PV generation and $410 \mathrm{MW}$ of CSP generation [61]. PTC has a significant benefit in the thermal conservation of electricity. Its annual power factor is 25 to 28 percent without thermal energy storage (TES) and 29 to 43 percent without thermal energy storage (TES) [62]. Solar thermal energy storage types include sensitive heat storage, thermal chemical storage, 
and latent heat storage [63]. The advantages of TES over other energy storage technologies are lower capital costs and higher operating efficiency. A local renewable microgrid with solar photovoltaic, biodiesel and biogas generators, including battery storage, enhances the dispatch ability of the plant with high-value ancillary services such as spinning reserve [64]. Its dynamic performance needs to be studied before the implementation of PTC in HPS. A very few works of literature have reported the dynamic performance of PTC-based HPS $[65,66]$.

\subsection{Energy Storing Components}

Most of the renewable energy sources have become an integral part of the main grid to supply the mainstream area [67-69]. The grid power should be of acceptable quality under stable operating conditions which may be compromised due to the high penetration of these sources in the main grid. However, this is very important for future generations to have better alternatives. Problems pertaining to having quality power can be overcome to some extent by the appropriate and efficient use of energy storage devices; like a future framework for grid integration of marine renewable energy, with one grid area being a huge interconnected grid area and the other being a smaller remotely connected island grid area. The system's versatility allows it to be modified for both large-scale and small-scale grid operations such as distant coastal villages, microgrids, and island HPS. When utilized in conjunction with other renewable sources, research shows that maritime energy can enhance storage capacity needs, especially in high renewable penetration situations. The degree and scope of that advantage, on the other hand, is highly dependent on several criteria, including location, profiles of other renewable resources, load profile, and availability, and the marine resources' persistence. Parametric studies are a critical initial step in analyzing such grid locations to plan the best renewable resource mix and storage technology [70]. The uncertainty of the non-conventional energy sources creates the importance of energy-storing components (ESCs). The significant importance of the storing devices is discussed in the number of simulation and real time-based articles wherein the used devices are Battery Energy Storage System (BESS), Superconducting Magnetic Energy Storage (SMES), Super-capacitor (SC), Ultra-capacitor (UC), Compressed Air Energy Storage (CAES), etc. [5,17-21,25,31,45,47,61,71-84].

In isolated HPS, ESCs are essential to bridge the gap between generation and demand by storing surplus power during higher penetration of the sources and delivering the stored power during the dearth of supply. In other words, it can be said that the natural intermittency of renewable energy sources will remain well manageable in the presence of ESCs. Many works ascertain the control of deviated frequency from its nominal figures by injecting or absorbing the active power through these devices [85-88]. In [85], PV based HPS is operated and controlled with the help of BESS. Here, the charging and discharging rate of the battery is the function of the variable loads. Variation in the loads decides the operational battery characteristics and thus controls the deviation in system parameters. Authors in [17] considered the battery as a dc link to support the system with active and reactive power and reduce the mismatch between load and the source. C. Tammineediin [86] has provided the significance of the battery in enhancing the performance of the system comprising non-conventional energy sources. Authors in [87] have ensured the system stability with greater flexibility in the planning of the HPS. At the same time, it approves the BESS's profitability and importance for diminishing frequency deviation. With the help of batteries, the capability to extract power from wind turbines has been significantly enhanced. Here, in literature [88], BESS has been used to manage the undisturbed transition of the power supply from the system consisting of an induction generator alone to the system consisting of a doubly fed induction generator and diesel-based synchronous generator. Therefore, it can be accepted that BESS has a vital position in HPS for smooth and continuous supply to the customers. A lot of studies are going on to enhance the capacity of the BESS at marginal expansion in its volume. There are some energy storage devices that provide a very fast response. 


\subsection{Fast Energy Acting Energy Devices Suitable for Frequency Control}

Response time of the energy storage devices is equally important to settle down the deviations in the system parameters at a faster rate. The importance of response time opens up the places in HPS for the ultra-capacitor (UC) and super-capacitor (SC) to diminish the stability problems. These devices follow the load change instantly and very closely to reduce appreciable deviation in the supply frequency. Depending on the requirements, fast responding devices like SC and UC are considered in many papers [71-74,76] to restrict the system frequency deviation within its possible limits. These devices are costly as compared to the batteries but they have been used for many isolated systems because some of the systems are likely to experience appreciable transient oscillations immediately after perturbation. A number of systems require very fast-acting devices whose response time should be as low as possible. UC has demonstrated a significant performance in overcoming the transient disturbances immediately, which has been discussed in $[39,71]$. The energy density of UC is undoubtedly very large as compared to the battery. The use of this device provides an instantaneous energy supply to any isolated system as it takes a lot less time to charge and also to discharge. Meanwhile, the efficiency of its cycle for charging and discharging is very high, which removes the transient spikes in the system in no time and regains a new stable equilibrium point for its operation faster. However, it provides the energy for a shorter duration of time which cannot give active and reactive power support to the system for a longer time period. In [39], the authors illustrate the dynamic behavior of the ultra-capacitor by developing the MATLAB/Simulink model of PV solar power with fuel cell in combination with UC. UC has fulfilled rapid load demand change for short intervals where Fuel cells (FC) could not respond to the load immediately. In [66], BESS and FC combined with UC is developed as HPS in which the energy devices respond to the system according to the defined priority. Here, the UC acts before FC because FC is slower than UC. UC is mainly used for the initial response to remove the transient oscillations from the system. The authors have considered the UC to remove the ripples from the system during the transient ensuring reduction in the heat and the loss in the battery due to ripples [71]. A significant amount of work has been done related to UC mainly to overcome the transient instability.

In addition to UC/SC, there is another energy storing device known as SMES which is much faster than UC/SC. SMES responds to the load quickly as it stores the energy in the form of the magnetic field. SMES has been applied with the HPS comprising of wind turbine generator and diesel generator mainly for controlling the power deviation at the initial stage [14]. As the transient time period is over, the Diesel Generator (DG) starts acting as a backup source and fulfills the demand [82]. The author has attempted to show the overview of different types of applications of SMES [83]. Its use in the power system clearly shows the potential of SMES where it has been signified that the SMES is very much cost-effective. Oscillation in the power and frequency of the grid due to insertion of the renewable energy sources can be significantly minimized through SMES because it has higher power density as compared to that of all other energy storing devices [80]. Renewable energy source with SMES has been realized as a dispatchable unit in this paper because of its higher power density only. Authors in [81] have shown the potential of SMES for the attenuation of power and frequency oscillations. The voltage source converter-based SMES smoothens the power supply of wind turbine generators which can provide quality power to the customers [82]. The intermittency of the renewable energy sources causing a large excursion in the frequency has been minimized at a very initial stage with the help of SMES in [84]. All the above papers related to the use of SMES in different proposed systems have clearly figured out that the power controlling capability of the SMES is very much appreciable. In addition to all the energy storing devices, Fuel Cell (FC) and Aqua-electrolyzer $(\mathrm{AE})$ also play a very significant role in mitigating the oscillations in the system parameters. Some research in $[71,72,74,78,79]$ has highlighted the requirements of FC from the economic point of view. 


\subsection{Plug-in-Electric Vehicles}

The entire world must grow with pollution-free technology. That's why naturefriendly technology is being given the utmost importance across the globe. Plug-in-Electric Vehicles (PEVs) can be regarded as one of them. The introduction of Plug-in-Electric Vehicles (PEVs) up to some extent can restore the pure atmospheric scenario. Meanwhile, the problems associated with the power system can also be resolved. Vehicles employed with the battery having higher energy density are nowadays participating in controlling the power flow of the power system. The dynamic model of Plug-in-Electric Vehicles has been developed to regulate the system frequency [89]. A large number of PEVs are available for the PEVs station, which provides regular and accurate signals to the PEVs to be connected or disconnected from the station as per the requirement. The EVs aggregator shares the proper information between EV and the controlling unit of the power system to maintain the system frequency. Authors have used the EVs as a secondary frequency controller to control the frequency of the main grid [90]. The same author has proposed the PEVs as the primary frequency controller for the isolated system as well. Authors in [91] have addressed the technical issues associated with the grid when the PEVs are penetrated in a very large amount. Due to the large number of PEVs, a huge power burden will be there on the grid that can be considered as one of the threats to the stable power system operation. The author has mentioned the clear demarcation in between loss and benefits and finally accepted that the proper coordination may keep the system under stable operation along with PEVs. A comparison between generalized and optimized patterns changing has been addressed in the work reported in [92] and has shown that the optimized pattern of charging is very much cost-effective and very much reliable. PEVs along with water heaters in distributed generation systems are also cost-effective and useful in limiting the frequency of excursions [93]. The authors in [94,95] have mentioned the requisites of PEVs to control the frequency of the isolated system based on renewable energy sources.

\section{Intermittency of RES in HPS, Consequent Voltage Fluctuation, and Its Solutions}

Another challenging issue for any power system is to control the voltage deviation. Voltage deviation in the system may happen due to a mismatch between source and load reactive power. The deviation in reactive power may lead the system voltage to go beyond or down from its rated value with a large difference. In other words, the system will suffer from problems like overvoltage and under-voltage. Overvoltage is an issue that often results in the insulation failure of the equipment whereas under voltage is a critical issue to be regularly monitored because it may lead to the total system collapse.

The problems aforementioned are apparently encountered in the HPS erected on the basis of renewable energy sources because they are highly intermittent. To harness energy from them, due to their intermittency, there is a need for generators that should operate at variable speed, so the induction generators are mostly considered for HPS consisting of RESs; but the induction generators have a drawback in that they require energy for their field excitation, resulting in a voltage drop at its terminal. Authors in [96] specify that the wind turbine is connected with an induction generator sometimes called an asynchronous generator for its operation. However, the diesel engine is also connected along with the induction generator as a backup source. Dish Stirling solar power (DSP) and wind turbine power have resemblance in their operations; hence, an asynchronous generator (Squirrel cage induction generator-SCIG) has been used for establishing a DSP power plant [97-99]. The authors in [100-102] have discussed the induction generators and their impacts on the system in the form of voltage stability. The paper [100] is one of the review papers in which the use of induction generators with renewable energy sources has been comprehensively discussed. In a literature survey in [90-100], the authors have clearly stated that the induction generators are of utmost importance for the HPS based on non-conventional energy sources; in the meanwhile, they have figured out that SCIG is the better option for these unpredictable sources. The advantages of SCIG are mentioned as simple construction, low maintenance cost, and being highly rugged in nature; but it 
requires reactive power for its operation, which may vary the terminal voltage and increase the voltage stability problems. Moreover, the power factor and efficiency of the system are also reduced [103]. To improve the voltage regulation of the system, SCIG has been replaced by PMIG in [93], because PMIG does not require reactive power for its field excitation. Electromagnetic poles are replaced by permanent magnetism in a permanent magnet induction generator (PMIG) which provides flux without any source of excitation. PMIG is superior to SCIG to provide voltage stability and reactive power support. PMIG delivers power at a higher efficiency to the grid even when the grid faces an unbalance in the voltage because PMIG has a higher power density and the negative sequence of the magnetic flux hardly affects PMIG [104]. The higher power density reduces its size and the inrush current; simultaneously, its responses at steady-state and transient disturbances are better as compared to IG [105]; but PMIG is mechanically weaker and costly [106]. In addition to PMIG, Permanent Magnet Synchronous Generator (PMSG) also has a better performance in HPS. Solid-state devices are used for their superior input, thermal characteristics to others because of the absence of field winding or the loss in the field winding which ultimately increases its efficiency, and its power density as compared to its weight is comparatively higher, which improves the dynamic behavior of PMSG [104,107,108].

Along with the employment of different competent generators, the voltage stability margin can be increased significantly with the justified use of different Voltage Controlling Devices (VCDs). VCDs mitigate the reactive power mismatch to restore the nominal voltage of the system. Different VCDs have been used for the isolated HPSs like Static Synchronous Compensator (STATCOM), Static Var Compensator (SVC), Unified Power Quality Conditioner (UPQC), and Dynamic Voltage Restorer (DVR) [104,108-113]. The application of SVC, STATCOM, and DVR become important for HPS, because these devices provide a faster dynamic response for stability enhancement [114-116]. Moreover, these devices reduce system power loss and harmonics. At a low voltage level, it can be operated over its full output current. Thanks to the advent of power electronic devices, the cost of SVC, STATCOM, and DVR is expected to come down.

Voltage regulation of the SVC-based HPS was addressed in $[105,117,118]$ and the response is basically viable. However, this mechanism has been considered a controller for SVC when the DG's excitation system is still set and cannot be assumed as a properly integrated approach. The researchers of [115] developed a similar form of simulation model to see device responses under SVC where different controllers are used for SVC and AVR for proper and realistic synchronization in the system.

Another reactive power control pertaining to the isolated hybrid system using STATCOM in presence of PMIG has been investigated in $[116,119]$. In this work also, the parameters of the STATCOM controllers were optimized, keeping the parameters of AVR constant. Moreover, the parameters of the STATCOM controller were optimized considering variable wind power with step reactive power load change. To include realistic features, the parameters (i.e., the controller parameters of the STATCOM and AVR) should have been optimized simultaneously considering random variations of load reactive power as well as variable reactive power absorbed by IG.

DVR attenuates the deviation in the voltage significantly and has the ability to provide the required amount of voltage support for the proper functioning of the system. The voltage is injected in series with the line through a transformer at different phase angles [117]. DVR plays a vital role in mitigating the voltage deviation that is why this device is used in removing the problems pertaining to voltage sags and swells. However, the application of DVR in HPS for voltage stabilization is depicted in [120]. The representation of different voltage compensating devices for renewable integrated HPS is displayed in Table 2. 
Table 2. A summary of different kinds of voltage compensating devices, controllers for voltage control, and other applications in the power system.

\begin{tabular}{|c|c|c|c|c|c|c|}
\hline Reference & System Parameters & $\begin{array}{l}\text { Voltage } \\
\text { Control }\end{array}$ & $\begin{array}{l}\text { Renewable } \\
\text { Energy }\end{array}$ & Controller & $\begin{array}{c}\text { Voltage } \\
\text { Compensating } \\
\text { Devices }\end{array}$ & Index \\
\hline [104] & Wind (IG/PMIG/PMSG), Diesel & $\checkmark$ & Wind & PI & STATCOM & ISE \\
\hline [100] & Wind (IG), Diesel & $\checkmark$ & Wind & $\mathrm{x}$ & SVC & ISE \\
\hline [110] & Wind (IG), Diesel (SG) & $\checkmark$ & Wind & PI & STATCOM & ISE \\
\hline [113] & DVR (IGBT, PWM inverter) & $x$ & $\mathrm{x}$ & Fuzzy logic & DVR & $\mathrm{x}$ \\
\hline [115] & Wind (IG), Diesel & $\checkmark$ & Wind & PI, $\mathrm{H} \infty$ & SVC and AVR & IAE \\
\hline [116] & Wind (PMIG), Diesel & $\checkmark$ & Wind & PI & STATCOM & ISE \\
\hline [118] & $\begin{array}{l}\text { Dish-stirling solar thermal } \\
\text { (DSTS), Diesel }\end{array}$ & $\checkmark$ & $\begin{array}{l}\text { Dish-stirling } \\
\text { solar thermal }\end{array}$ & PI & SVC & IAE \\
\hline [119] & DSTS, Diesel & $\checkmark$ & DSTS & PI & $\begin{array}{l}\text { STATCOM and } \\
\text { AVR }\end{array}$ & ISE \\
\hline [120] & $\begin{array}{l}\text { Parabolic trough solar power } \\
\text { (PSP), thermal DSTS, Diesel }\end{array}$ & $\checkmark$ & PSP, DSTS & PI & $\begin{array}{l}\text { SVC, STATCOM, } \\
\text { DVR }\end{array}$ & ISE \\
\hline [131] & $\begin{array}{l}\text { Wind, Linear fresnel solar } \\
\text { thermal (LFR), Biodiesel, Biogas, } \\
\text { Biomass, Micro hydro turbine }\end{array}$ & $\checkmark$ & Wind, LFR & PID & AVR & ISWAE \\
\hline [137] & $\begin{array}{c}\text { Solar PV, Wind, LFR, Biodiesel, } \\
\text { Biogas, Biomass }\end{array}$ & $\checkmark$ & $\begin{array}{l}\text { Solar PV, Wind, } \\
\text { LFR }\end{array}$ & PID & AVR & ISWAE \\
\hline
\end{tabular}

Where tick mark $(\checkmark)$ represents presence of feature and cross mark (x) represents absence of feature in the system.

\section{Energy Management and Demand Response in HPS}

Different generating units with different auxiliary devices are considered to develop the HPS according to the location and the climate which have been mentioned in the above literature surveys. A number of studies [20-25] have discussed the mathematical modeling of the HPS. According to the load, the size (rating) of the power system is also very important to be taken care of. The issues related to the size of the power system have been addressed in [26,27]. In [27], the authors have discussed the unit sizing method to calculate the size of different subsystems considered in the system which will help to minimize the variance between generated renewable power and demanded loads over a span of time. The size of the different subsystems is also depicted in [27]. Besides the system development according to the requirements, the proper control strategies also form a significant part of the system for smooth operation, which is addressed in a number of studies [38-41]. Nowadays, energy and power management have also been a crucial part of controlling the deviation in the system parameters. In other words, it can be said that the customers' active involvement in the power system can play a very important role in system control. Authors in $[75,121]$ have regarded energy management as one of the important tools for providing good quality of power to the customers.

These days, demand response schemes (DRS) have established a clear recognition in frequency control $[122,123]$. During typical grid operations, current transactive controllers use marginal gains and marginal costs to enhance economic market efficiency. However, because system operations during contingencies are typically governed by technical needs rather than simply economic factors, the transactive mechanisms established for normal economic operations cannot be readily adapted to contingencies such as black start and system recovery by using resource commitment along with service recovery approach in case of HPS [124,125]. Devices used in DRS are normally non-critical loads (NCL) like air conditioners, freezes, different types of electric water heaters $(\mathrm{EWH})$, and so on. In addition, different control strategies are developed in DRS which are as follows: linear quadratic regulator (LQR), Ho control, hill-climbing method, and so on [126,127]. Most of the above methods are used for an isolated system. In [116], DRS is also implemented to control the frequency of the 
interconnected areas with non-conventional energy resources [128-136], where the application of DRS for concurrent frequency and voltage stabilization is established in [137].

\section{Different Controllers Adopted in HPS}

To control all of the HPS's devices below their functional limits, proper synchronization between them must be established. As a result, the HPS are controlled using various traditional controls such as Proportional (P), Proportional-Integral (PI), and ProportionalIntegral-Derivative (PID), as defined in [45,48,50,67,68,74,100,102,104,109,116,117,138-143]. Other controllers, like the Ho controller, A Two Degree of Freedom (2DOF) PI/PID controllers, fractional-order (FO) based controllers, and double stage controller, are often included in several of the cases discussed in $[129,130,143-153]$ as listed in Table 3 below. Figure 2 shows the overall control strategy for the hybrid power system along with conventional and non-conventional renewable energy sources.

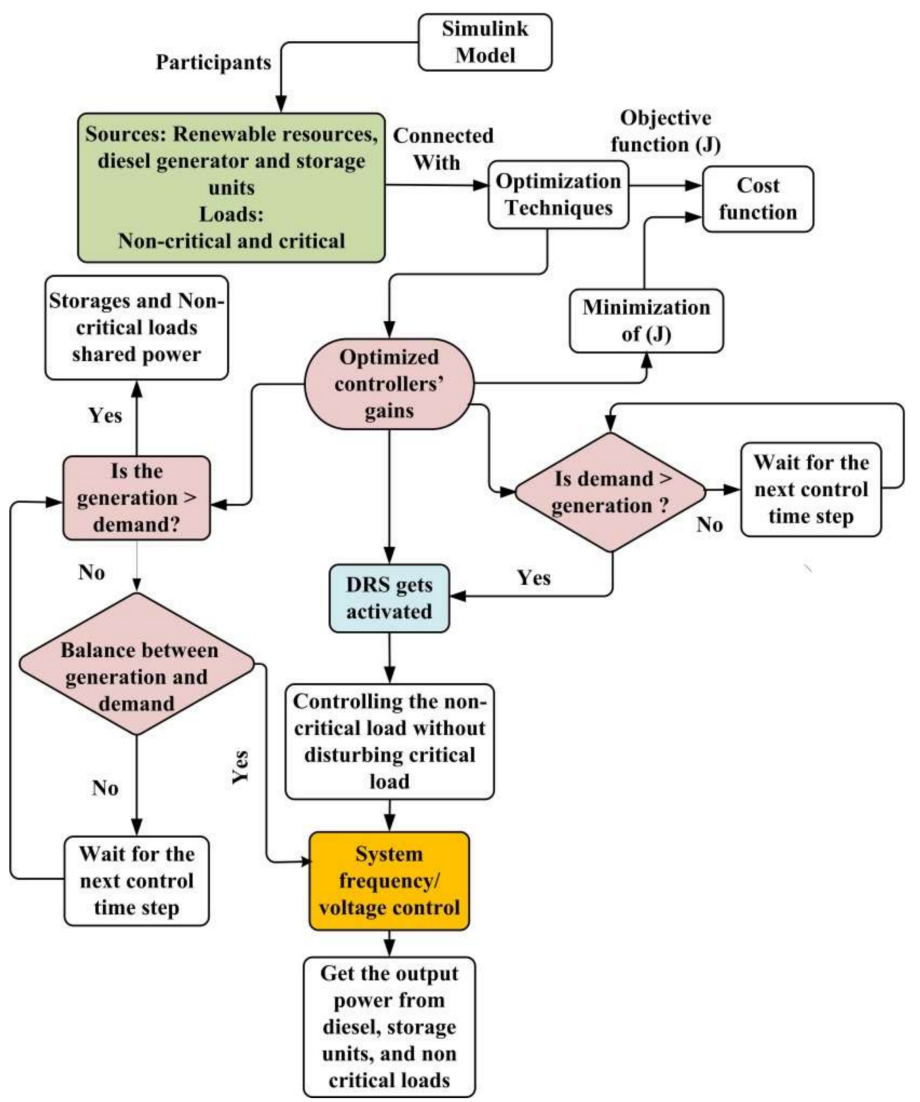

Figure 2. Structure of control strategy for renewable based HPS.

Identifying an appropriate optimization tool for tuning of the controllers is no less important. To this end, many researchers $[5,15,45,46,67,68,103,111,137-144,148,154-160]$ have obtained optimum performance of HPS using different intelligent techniques such as Genetic Algorithm (GA), Particle Swarm Optimization (PSO), Fuzzy Logic Control, Yellow Saddle Goatfish Algorithm (YSGA), Butterfly Optimization Technique (BOA) and so on. A number of papers have been published in the past few years that focus on the application of PSO as well as Cuckoo Search (CS). PSO technique has been applied in solving several types of optimization problems, for example, highly nonlinear, highly complex, discontinuous, non-differentiable problems [142]. Cuckoo search is a new meta-heuristic search algorithm inspired by the obligate brood parasitic behavior of some cuckoo species, developed by Xin-she Yang and Suash Deb $[143,144]$. It has been reported that it is capable of outperforming other optimization techniques [144] like GA. Social Spider Optimizer (SSO) [5] is used in two area hybrid systems. To control the frequency of isolated HPS, the Flower Pol- 
lination Algorithm (FPA) and Firefly Algorithm (FA) is used. AGC has enabled the use of the Bacterial Foraging Optimization Algorithm (BFOA), Differential Evolution (DE) [157], and Teaching Learning Based Optimization [136]. Sadollah, Ali et. al developed the mine blast algorithm (MBA) as a more recent meta-heuristic algorithm $[159,161]$, which has also been used to optimize controller parameters, and their output has been compared to that of CS and PSO. MBA was considered by the authors in $[155,161]$ to tune the controllers' parameters to regulate the voltage and frequency of the unit. For reactive power analysis of an isolated HPS consisting of the dish-Stirling solar power system (DSP), PSP, diesel engine generator (DEG), static VAR compensator (SVC), static synchronous compensator (STATCOM), and dynamic voltage restorer (DVR) have been conducted [115-117]. A diesel engine coupled to a synchronous generator equipped with Automatic Voltage Regulator (AVR), DSP is connected to an induction generator (IG) and PSP is connected to permanent magnet synchronous generator (PMSG). The parameters of the PI controllers, employed with AVR, SVC, STATCOM, and DVR, are optimized using the mine blast algorithm (MBA) $[159,161,162]$. Additionally, the HPS has been investigated under SVC, STATCOM, and DVR, where DVR outperforms the other two [113,116].

Table 3. Optimization techniques with merits and demerits.

\begin{tabular}{|c|c|c|c|}
\hline References & $\begin{array}{l}\text { Optimization Techniques of } \\
\text { Tuning Controllers }\end{array}$ & & Merits/Demerits \\
\hline $\begin{array}{l}{[5,15,45,46,67,68,103,109,138-} \\
\quad 145,151,154,156,157]\end{array}$ & $\begin{array}{l}\text { Intelligent methods such as GA, } \\
\text { PSO, FUZZY logic control }\end{array}$ & $\begin{array}{l}(1) \\
(2) \\
(3) \\
(4) \\
(5) \\
(6)\end{array}$ & $\begin{array}{l}\text { Optimization techniques are robust. } \\
\text { Easily run the parallel computation. } \\
\text { Easy to understand. } \\
\text { Fuzzy logic can easily handle the complex problem. } \\
\text { However, Fuzzy logic needs clear parameters identification. } \\
\text { These optimization techniques are computationally expensive. }\end{array}$ \\
\hline$[144,145]$ & CS & $\begin{array}{l}(1) \\
(2) \\
(3) \\
(4)\end{array}$ & $\begin{array}{l}\text { Effective in practical application. } \\
\text { Very useful to solve the continuous problem. } \\
\text { It does not perform well for the discrete and } \\
\text { multi-objective problem. } \\
\text { It faces problems in adaptability and optimal search results. }\end{array}$ \\
\hline [5] & SSO & $\begin{array}{l}(1) \\
(2) \\
(3)\end{array}$ & $\begin{array}{l}\text { Enhance performance. } \\
\text { Linear time complexity. } \\
\text { Need more computational time. }\end{array}$ \\
\hline$[126,127,150]$ & FPA and FA, hill-climbing method & $\begin{array}{l}(1) \\
(2) \\
(3) \\
(4)\end{array}$ & $\begin{array}{l}\text { Very simple to get the solution. } \\
\text { Increase linking connection. } \\
\text { Effectively recognize the optimal mean policies via an adjustable } \\
\text { learning rate. } \\
\text { Higher elapsed time. }\end{array}$ \\
\hline [157] & BFOA, DE & $\begin{array}{l}(1) \\
(2)\end{array}$ & $\begin{array}{l}\text { Easy to handle non-linear and multi-objective functions. } \\
\text { Provide results with the minimum number of control parameters. }\end{array}$ \\
\hline$[155,159,161,162]$ & (MBA) & $\begin{array}{l}(1) \\
(2)\end{array}$ & $\begin{array}{l}\text { Enhanced convergence speed.Better searching ability leads to } \\
\text { improved exploration. } \\
\text { Reduced function value. }\end{array}$ \\
\hline
\end{tabular}

In light of the literature survey, this section presents three area hybrid power systems (3A-HPS) based on three different renewable energy sources like WTG, PSP, and PV arrays in all three areas, respectively, along with DGs as a backup source of supply. WTG, PSP, and PV arrays are associated with superconducting magnetic energy storage (SMES), ultra-capacitor (UC), and BESS. Different controllers like PID, PID with filters (PIDN), and two degrees of freedom PID (2DOF-PID) controllers are employed separately at a time with DEG, BESS, SMES, and UC so as to adjust the output power in response to the change in loading and or output power variation of renewable sources. The parameters of the controllers are optimized using Genetic Algorithm (GA), Particle Swarm Optimization (PSO), and Mine Blast Algorithm (MBA).

Figure 3 presents three area 3A-HPS based on three different renewable energy sources like WTG, PSP, and PV arrays in all three areas respectively along with DGs as a backup 
source of supply. PSP and PV arrays are associated with biogas power systems (BGPS). PEVs are connected in each area in place of the energy storage devices to dynamically participate to overcome the cost-related issues and climatic disturbances.

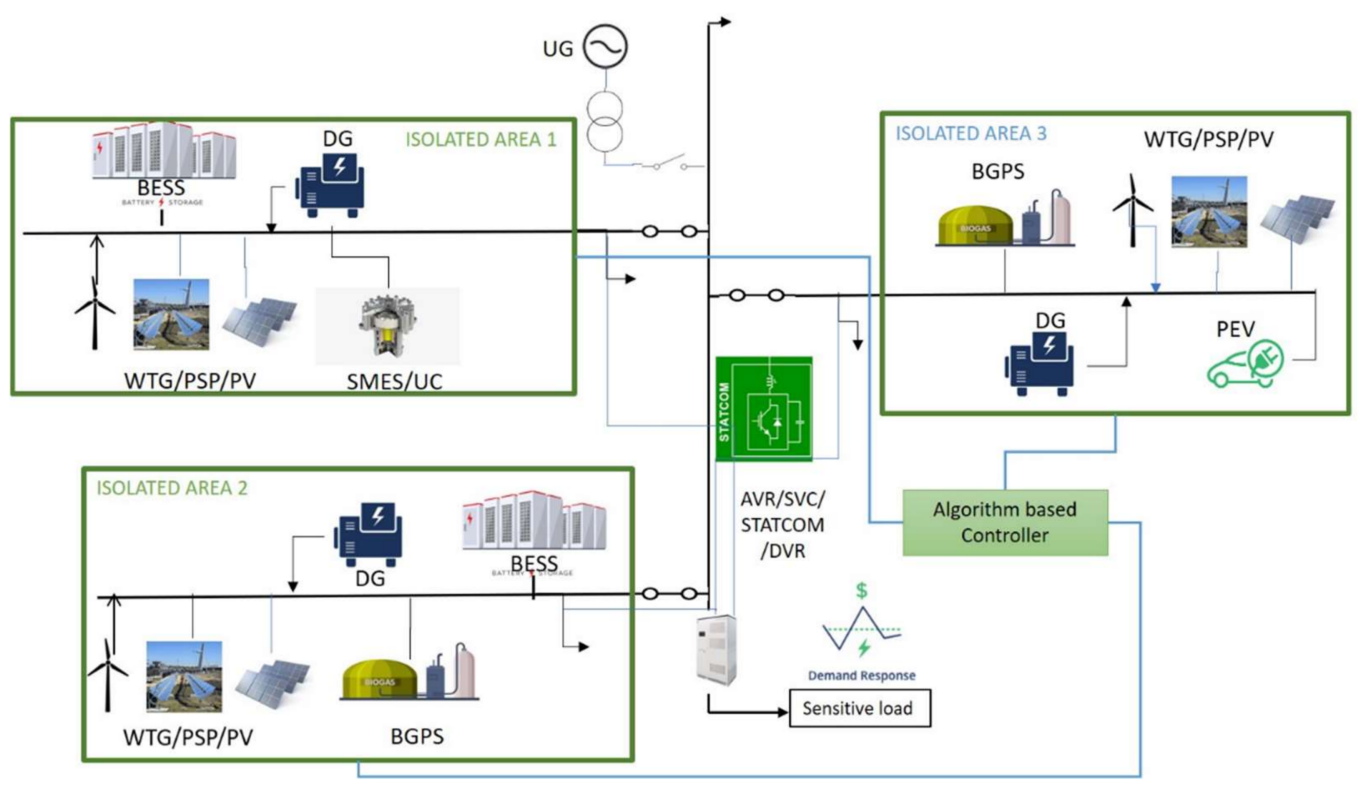

Figure 3. Representational diagram of the 3A-HPS.

The system consists of a solar photovoltaic array and a hybrid solar-thermal with Biogas power, which also is intended to obtain electricity from the community's biodegradable waste. A biodiesel generator and battery storage are both included in the system to cope with power variability $[147,150]$. Additionally, the comparative performance of 3A-HPS in the presence and the absence of PEVs have been investigated under step and random variation in the generation and in the load. It reveals that PEVs associated with HPS perform better in mitigating the power and frequency deviation [82-84].

\section{Future Research Directions}

The analysis of voltage and frequency control of multi-area HPS comprising of WTG, PSP, DSP, and DG in the presence of BESS, SMES, and UC, WTG, PSP, DSP along with DG in the presence of Static Var Compensator (SVC), static synchronous compensator (STATCOM), and dynamic voltage restorer (DVR), have been trends of research for over a decade. Most of the works follow conventional PID controllers' optimization to contain voltage oscillations, where some advanced control stratagems are essential with some other novel RESs. Considering the above literature review, the scope of the research that should be highlighted is pointed out herewith:

- Analysis of some novel RESs and their participation in concurrent voltage-frequency (v-f) stabilization of HPS.

- Incorporation of deregulation in the HPS's voltage-frequency regulation is the future possible solution that needs to be explored, where a participation matrix was formed to interact between generation and distribution companies.

- In continuation of the above research, a different control stratagem is needed to stabilize and enhance the single/multi-area HPS network system dynamics.

- Implementation of some maiden controllers' (i.e., triple-layer, cascaded tilt integral derivative) optimization approach, which could stabilize the system dynamics under different uncertainties.

- Formulation of some new fitness function (J) index to regulate the system dynamics in a better fashion, where weight factor put a significant role on enhancing the dynamic system responses. 
- Application of machine learning approach in concurrent $\mathrm{v}-\mathrm{f}$ stabilization needs to be explored.

- Development of virtual-physical HPS and its coordinated control phenomenon.

- Establishing an optimal control strategy to identify different faults and protect the renewable HPS network.

- The communication design for coordinated control of different components in HPS can be further explored.

- Impact of different cyber-attacks on HPS networks can be studied. Furthermore, mitigation strategies against cyber-attacks in HPS can be formulated.

Further, to improve the system dynamics, the utilization of virtual inertia control (VIC) could be a future possible solution that needs to develop. To guarantee that prospective electrical grids are sustainable, economical, reliable, and self-healing, it is expected to resolve all of the simultaneous emerging shifts and transformations in the electrical grid with practical, statistical, proven, and integrative studies and research.

\section{Conclusions}

A thorough analysis of the literature provided a great deal of information regarding the erection of the isolated HPS comprised of RESs. It can be realized that RESs are the important solution to fulfill the energy crisis at the minimum level of pollution. RESs, which are not thoroughly investigated to develop the HPS, can be considered and realized. It can be clearly figured out that the characteristics of the RESs impact the system stability in the form of voltage and frequency oscillations which require economical and robust control strategies. A system developed with the help of RESs and different ESCs requires a proper coordinating control mechanism which can be achieved by selecting the appropriate and intelligent soft computing algorithms like Genetic Algorithm (GA), Particle Swarm Optimization (PSO), Cuckoo Search Algorithm (CSA), and Mine Blast Algorithm (MBA). The selection of the optimal parameters of the controllers under the influence of soft computing techniques according to the problems defined is essential to restore the system's stability. The considered HPS is likely to undergo large excursions in the voltage and frequency due to the uncertainty and random nature of the solar irradiances, temperature, and the wind velocity of the wind turbine. A solution to compensate for the randomness of the supply of RESs, better controlling actions are required. Throughout the work has been analyzed how simultaneous control of voltage and frequency of HPSs consisting of RESs of different nature is one of the challenging assignments, where MBA-based 2DOF PID controllers outperform other controlling strategies. Thus, it can be said that the MBA-based 2DOF PID controller may be a viable option for controlling any hybrid power system. Abovementioned controlling schemes could be expected to have a great degree of reliability and controllability from all the practical and technical aspects. The considered system with this controlling scheme would be realizable and acceptable within all the practical constraints.

Author Contributions: Conceptualization, S.R., A.L., S.J. and D.C.D.; methodology, S.R., A.L., S.J,, D.C.D. and S.M.S.H.; formal analysis, S.R., A.L., S.J., D.C.D. and S.M.S.H.; investigation, S.R., A.L., S.J., D.C.D. and S.M.S.H.; resources, D.C.D., N.S. and T.S.U.; writing - original draft preparation, S.R., S.J. and A.L.; writing—review and editing, D.C.D., N.S., S.M.S.H. and T.S.U.; visualization, S.R., A.L., S.J., D.C.D. and S.M.S.H.; supervision, D.C.D. and N.S.; project administration, S.M.S.H. and T.S.U.; funding acquisition, T.S.U. All authors have read and agreed to the published version of the manuscript.

Funding: This research received no external funding.

Data Availability Statement: Not applicable.

Conflicts of Interest: The authors declare no conflict of interest. 


\section{Abbreviations}

\begin{tabular}{|c|c|c|c|}
\hline HPS & Hybrid Power System & DVR & Dynamic Voltage Restorer \\
\hline PV & Photovoltaic & DSP & Dish Stirling Solar Power \\
\hline RES & Renewable Energy Sources & AVR & $\begin{array}{l}\text { Automatic Voltage } \\
\text { Regulator }\end{array}$ \\
\hline BESS & $\begin{array}{l}\text { Battery Energy Storage } \\
\text { System }\end{array}$ & IG & Induction Generator \\
\hline TES & Thermal Energy Storage & PWM & Pulse Width Modulation \\
\hline CSP & Concentrated Solar Power & IGBTs & $\begin{array}{l}\text { Insulated Gate Bipolar } \\
\text { Transistors }\end{array}$ \\
\hline STP & Sewage Treatment Plant & DSTS & Dish-Stirling Solar Thermal \\
\hline SMES & $\begin{array}{l}\text { Superconducting Magnetic } \\
\text { Energy Storage }\end{array}$ & PSP & $\begin{array}{l}\text { Parabolic Trough Solar } \\
\text { Power }\end{array}$ \\
\hline ESCs & $\begin{array}{l}\text { Energy Storing } \\
\text { Components }\end{array}$ & LFR & $\begin{array}{l}\text { Linear Fresnel Solar } \\
\text { Thermal }\end{array}$ \\
\hline $\begin{array}{l}\mathrm{SC} \\
\mathrm{UC}\end{array}$ & $\begin{array}{l}\text { Super-Capacitor } \\
\text { Ultra-Capacitor }\end{array}$ & $\begin{array}{l}\text { DRS } \\
\text { NCL }\end{array}$ & $\begin{array}{l}\text { Demand Response Schemes } \\
\text { Non-Critical Loads }\end{array}$ \\
\hline CAES & $\begin{array}{l}\text { Compressed Air Energy } \\
\text { Storage }\end{array}$ & EWH & Electric Water Heaters \\
\hline PTC & $\begin{array}{l}\text { Parabolic Trough Solar } \\
\text { Collector }\end{array}$ & LQR & Linear Quadratic Regulator \\
\hline FC & Fuel Cells & GA & Genetic Algorithm \\
\hline DG & Diesel Generator & PSO & $\begin{array}{l}\text { Particle Swarm } \\
\text { Optimization }\end{array}$ \\
\hline AE & Aqua-Electrolyzer & YSGA & $\begin{array}{l}\text { Yellow Saddle Goatfish } \\
\text { Algorithm }\end{array}$ \\
\hline PEV & Plug-In-Electric Vehicles & BOA & $\begin{array}{l}\text { Butterfly Optimization } \\
\text { Technique }\end{array}$ \\
\hline SCIG & $\begin{array}{l}\text { Squirrel Cage Induction } \\
\text { Generator }\end{array}$ & SSO & Social Spider Optimizer \\
\hline PMIG & $\begin{array}{l}\text { Permanent Magnet } \\
\text { Induction Generator }\end{array}$ & FPA & $\begin{array}{l}\text { Flower Pollination } \\
\text { Algorithm }\end{array}$ \\
\hline PMSG & $\begin{array}{l}\text { Permanent Magnet } \\
\text { Synchronous Generator }\end{array}$ & FA & Firefly Algorithm \\
\hline VCDs & Volage Controlling Devices & BFOA & $\begin{array}{l}\text { Bacteria Foraging } \\
\text { Optimization Algorithm }\end{array}$ \\
\hline STATCOM & $\begin{array}{l}\text { Static Synchronous } \\
\text { Compensator }\end{array}$ & MBA & Mine Blast Algorithm \\
\hline $\begin{array}{l}\text { SVC } \\
\text { UPQC }\end{array}$ & $\begin{array}{l}\text { Static Var Compensator } \\
\text { Power Quality Conditioner }\end{array}$ & $\begin{array}{l}\text { BGPS } \\
\text { VIC }\end{array}$ & $\begin{array}{l}\text { Biogas Power System } \\
\text { Virtual Inertia Control }\end{array}$ \\
\hline
\end{tabular}

\section{References}

1. Available online: https://sustainabledevelopment.un.org/content/documents/2019_Tracking_SDG7_Report (accessed on 10 November 2021).

2. Zhang, Y.; Wang, X.; Zhang, W.; Hou, F.; Wu, Z. Analysis of technical strategies towards a low carbon electricity system in Europe. In Proceedings of the 5th International Conference on Electric Utility Deregulation and Restructuring and Power Technologies (DRPT), Changsha, China, 26-29 November 2015; pp. 2561-2565.

3. Qazi, A.; Hussain, F.; Rahim, N.A.; Hardaker, G.; Alghazzawi, D.; Shaban, K.; Haruna, K. Towards Sustainable Energy: A Systematic Review of Renewable Energy Sources, Technologies, and Public Opinions. IEEE Access 2019, 7, 63837-63851. [CrossRef]

4. Gururaj, M.V.; Inatha, U.V.; Jayasankar, V.N. Interconnection of wind-solar hybrid Renewable Energy source to the 3 phase-3 wire distribution system along with power quality improvements at the grid side. In Proceedings of the International Conference on Power and Advanced Control Engineering (ICPACE), Bangalore, India, 12-14 August 2015; pp. 168-172.

5. El-Fergany, A.A.; El-Hameed, M.A. Efficient frequency controllers for autonomous two-area hybrid microgrid system using social-spider optimizer. IET Gener. Transm. Distrib. 2017, 11, 637-648. [CrossRef]

6. Fiorentzis, K.; Katsigiannis, Y.; Karapidakis, E. Full-Scale Implementation of RES and Storage in an Island Energy System. Inventions 2020, 5, 52. [CrossRef]

7. Li, Y.; Gao, D.W.; Gao, W.; Zhang, H.; Zhou, J. Double-mode energy management for multi-energy system via distributed dynamic event-triggered Newton-raphson algorithm. IEEE Trans. Smart Grid 2020, 11, 5339-5356. [CrossRef]

8. Gabash, A.; Li, P. Active-Reactive Optimal Power Flow in Distribution Networks with Embedded Generation and Battery Storage. IEEE Trans. Power Syst. 2012, 27, 2026-2035. [CrossRef]

9. Gabash, A.; Alkal, M.; Li, P. Impact of Allowed Reverse Active Power Flow on Planning PVs and BSSs in Distribution Networks Considering Demand and EVs Growth. In IEEE Power and Energy Student Summit (PESS); IEEEL: Bielefeld, Germany, 2013; pp. 11-16.

10. Gabash, A.; Li, P. On the control of main substations between transmission and distribution systems. In Proceedings of the 2014 14th International Conference on Environment and Electrical Engineering, EEEIC, Krakow, Poland, 10-12 May 2014; pp. 280-285.

11. Alramlawi, M.; Gabash, A.; Mohagheghi, E.; Li, P. Optimal operation of hybrid PV-battery system considering grid scheduled blackouts and battery lifetime. Sol. Energy 2018, 161, 125-137. [CrossRef]

12. Mohagheghi, E.; Alramlawi, M.; Gabash, A.; Blaabjerg, F.; Li, P. Real-Time Active-Reactive Optimal Power Flow with Flexible Operation of Battery Storage Systems. Energies 2020, 13, 1697. [CrossRef] 
13. Tsitsovits, A.J.; Freris, L.L. Dynamics of an isolated power system supplied from diesel and wind. IEE Proc. A Phys. Sci. Meas. Instrum. Manag. Educ. Rev. 1983, 130, 587-595. [CrossRef]

14. Infield, D.G.; Slack, G.W.; Lipman, N.H.; Musgrove, P.J. Review of wind/diesel strategies. IEE Proc. A Phys. Sci. Meas. Instrum. Manag. Educ. Rev. 1983, 130, 613-619. [CrossRef]

15. Scott, G.W.; Wilreker, V.F.; Shaltens, R.K. Wind turbine generator interaction with diesel generators on an isolated power system. IEEE Trans. Power Appar. Syst. 1984, 5, 933-937. [CrossRef]

16. Lipman, N.H. Wind-Diesel and Autonomous Energy Systems; Elservier Science Publishers Ltd.: Cambridge, UK, 1989.

17. Lagorse, J.; Simoes, M.G.; Miraoui, A. A Multiagent Fuzzy-Logic-Based Energy Management of Hybrid Systems. IEEE Trans. Ind. Appl. 2009, 45, 2123-2129. [CrossRef]

18. Pan, W.; Gao, W.; Muljadi, E. The dynamic performance and effect of hybrid renewable power system with diesel/wind/PV/battery. In Proceedings of the International Conference on Sustainable Power Generation and Supply, Nanjing, China, 6-7 April 2009; pp. 1-5.

19. Goel, P.K.; Singh, B.; Murthy, S.S.; Kishore, N. Isolated Wind-Hydro Hybrid System Using Cage Generators and Battery Storage. IEEE Trans. Ind. Electron. 2011, 58, 1141-1153. [CrossRef]

20. Pahlevani, M.; Eren, S.; Guerrero, J.M.; Jain, P. A Hybrid Estimator for Active/Reactive Power Control of Single-Phase Distributed Generation Systems with Energy Storage. IEEE Trans. Power Electron. 2016, 31, 2919-2936. [CrossRef]

21. Tripathy, S.C.; Kalantar, M.; Balasubramanian, R. Dynamics and stability of wind and diesel turbine generators with superconducting magnetic energy storage unit on an isolated power system. IEEE Trans. Energy Convers. 1991, 6, 579-585. [CrossRef]

22. Khan, M.J.; Iqbal, M.T. Dynamic modeling and simulation of a small wind-fuel cell hybrid energy system. Renew. Energy 2005, 30, 421-439. [CrossRef]

23. Rajashekara, K. Hybrid fuel-cell strategies for clean power generation. IEEE Trans. Ind. Appl. 2005, 41, 682-689. [CrossRef]

24. Ashok, S. Optimised model for community-based hybrid energy system. Renew. Energy 2007, 32, 1155-1164. [CrossRef]

25. Deshmukh, M.K.; Deshmukh, S.S. Modeling of hybrid renewable energy systems. Renew. Sustain. Energy Rev. 2008, 12, 235-249. [CrossRef]

26. Jain, S.; Agarwal, V. An integrated hybrid power supply for distributed generation applications fed by nonconventional energy sources. IEEE Trans. Energy Convers. 2008, 23, 622-631. [CrossRef]

27. Wang, C.; Nehrir, M.H. Power management of a stand-alone wind/photovoltaic/fuel cell energy system. IEEE Trans. Energy Convers. 2008, 23, 957-967. [CrossRef]

28. Agyenim-Boateng, K. Energy-Based Analysis of Utility Scale Hybrid Power Systems. Master's Thesis, University of Nevada, Las Vegas, NV, USA, 2011. [CrossRef]

29. Bajpai, P.; Dash, V. Hybrid renewable energy systems for power generation in stand-alone applications: A review. Renew. Sustain. Energy Rev. 2012, 16, 2926-2939. [CrossRef]

30. Nayar, C.V.; Phillips, S.J.; James, W.L.; Pryor, T.L.; Remmer, D. Novel wind/diesel/battery hybrid energy system. Sol. Energy 1993, 51, 65-78. [CrossRef]

31. Bagul, A.D.; Salameh, Z.M.; Borowy, B. Sizing of a stand-alone hybrid wind-photovoltaic system using a three-event probability density approximation. Sol. Energy 1996, 56, 323-335. [CrossRef]

32. Nayar, C.V.; Thomas, F.P.; Phillips, S.J.; James, W.L. Design considerations for appropriate wind energy systems in developing countries. Renew. Energy 1991, 1, 713-722. [CrossRef]

33. Bhuiyan, M.M.H.; Asgar, M.A. Sizing of a stand-alone photovoltaic power system at Dhaka. Renew. Energy 2003, 28, 929-938. [CrossRef]

34. Gabash, A.; Li, P. On Variable Reverse Power Flow-Part I: Active-Reactive Optimal Power Flow with Reactive Power of Wind Stations. Energies 2016, 9, 121. [CrossRef]

35. Gabash, A.; Li, P. On Variable Reverse Power Flow-Part II: An Electricity Market Model Considering Wind Station Size and Location. Energies 2016, 9, 235. [CrossRef]

36. Kellogg, W.D.; Nehrir, M.H.; Venkataramanan, G.; Gerez, V. Generation unit sizing and cost analysis for stand-alone wind, photovoltaic, and hybrid wind/PV systems. IEEE Trans. Energy Convers. 1998, 13, 70-75. [CrossRef]

37. Elhadidy, M.A.; Shaahid, S.M. Parametric study of hybrid (wind + solar + diesel) power generating systems. Renew. Energy 2000, 21, 129-139. [CrossRef]

38. Nema, P.; Nema, R.K.; Rangnekar, S. A current and future state of art development of hybrid energy system using wind and PV-solar: A review. Renew. Sustain. Energy Rev. 2009, 13, 2096-2103. [CrossRef]

39. Uzunoglu, M.; Onar, O.C.; Alam, M.S. Modeling, control and simulation of a PV/FC/UC based hybrid power generation system for stand-alone applications. Renew. Energy 2009, 34, 509-520. [CrossRef]

40. Weldemariam, L.E. Genset-Solar-Wind Hybrid Power System of Off-Grid Power Station for Rural Applications; Delft University of Technology (TU Delft): Delft, The Netherlands, 2010.

41. Zhou, T.; François, B. Energy management and power control of a hybrid active wind generator for distributed power generation and grid integration. IEEE Trans. Ind. Electron. 2011, 58, 95-104. [CrossRef]

42. Eid, A. Control of hybrid energy systems micro-grid, in Smart Energy Grid Engineering (SEGE). In Proceedings of the IEEE International Conference on Smart Energy Grid Engineering (SEGE), Oshawa, ON, Canada, 28-30 August 2013; pp. 1-6.

43. Kaneko, T.; Uehara, A.; Senjyu, T.; Yona, A.; Urasaki, N. An integrated control method for a wind farm to reduce frequency deviations in a small power system. Appl. Energy 2011, 88, 1049-1058. [CrossRef] 
44. Nayeripour, M.; Hoseintabar, M.; Niknam, T. Frequency deviation control by coordination control of FC and double-layer capacitor in an autonomous hybrid renewable energy power generation system. Renew. Energy 2011, 36, 1741-1746. [CrossRef]

45. Das, D.C.; Roy, A.K.; Sinha, N. PSO based frequency controller for wind-solar-diesel hybrid energy generation/energy storage system. In Proceedings of the 2011 International Conference on Energy, Automation and Signal, ICEAS-2011, Bhubaneswar, India, 28-30 December 2011; pp. 458-463.

46. Gargoom, A.; Haruni, A.M.O.; Haque, M.E.; Negnevitsky, M. Smooth synchronisation and power sharing schemes for high penetration wind diesel hybrid remote area power systems. Aust. J. Electr. Electron. Eng. 2011, 8, 75-84. [CrossRef]

47. Das, D.C.; Roy, A.K.; Sinha, N. GA based frequency controller for solar thermal-diesel-wind hybrid energy generation/energy storage system. Int. J. Electr. Power Energy Syst. 2012, 43, 262-279. [CrossRef]

48. Singh, V.P.; Mohanty, S.R.; Kishor, N.; Ray, P.K. Robust H-infinity load frequency control in hybrid distributed generation system. Int. J. Electr. Power Energy Syst. 2013, 46, 294-305. [CrossRef]

49. Torres Lépez, M.A. Dynamic Frequency Control in Diesel-Hybrid Autonomous Power Systems using Virtual Synchronous Machines. Ph.D. Thesis, Concordia University, Montreal, QC, Canada, 2013.

50. Rawat, S.; Singh, S.; Gaur, K. Load frequency control of a hybrid renewable power system with fuel cell system. In Proceedings of the Power India International Conference (PIICON), 2014 6th IEEE, Delhi, India, 5-7 December 2014; pp. 1-6.

51. Gampa, S.R.; Das, D. Electrical Power and Energy Systems Real power and frequency control of a small isolated power system. Int. J. Electr. Power Energy Syst. 2015, 64, 221-232. [CrossRef]

52. Choi, J.W.; Heo, S.Y.; Kim, M.K. Hybrid operation strategy of wind energy storage system for power grid frequency regulation. IET Gener. Transm. Distrib. 2016, 10, 736-749. [CrossRef]

53. Lamzouri, F.E.Z.; Boufounas, E.M.; El Amrani, A. Efficient energy management and robust power control of a stand-alone wind-photovoltaic hybrid system with battery storage. J. Energy Storage 2021, 42, 103044. [CrossRef]

54. Buzas, J. Block-oriented Modeling of Solar Thermal Systems. Ph.D. Thesis, Szent Istvan University, Gödöllő, Hungary, 2006.

55. Machinda, G.T.; Chowdhury, S.; Arscott, R.; Kibaara, S. Concentrating solar thermal power technologies: A review. In Proceedings of the North American Power Symposium (NAPS), Starkville, MS, USA, 4-6 October 2009.

56. Cabeza, L.F.; Sole, C.; Castell, A.; Oró, E.; Gil, A. Review of solar thermal storage techniques and associated heat transfer technologies. Proc. IEEE 2012, 18, 525-538. [CrossRef]

57. Soliman, M.S.; Belkhier, Y.; Ullah, N.; Achour, A.; Alharbi, Y.M.; Al Alahmadi, A.A.; Abeida, H.; Khraisat, Y.S.H. Supervisory energy management of a hybrid battery/PV/tidal/wind sources integrated in DC-microgrid energy storage system. Energy Rep. 2021, 7, 7728-7740. [CrossRef]

58. Eddine Boukelia, T.; Mecibah, M.S. Parabolic trough solar thermal power plant: Potential, and projects development in Algeria. Renew. Sustain. Energy Rev. 2013, 21, 288-297. [CrossRef]

59. Cicilio, P.; Glennon, D.; Mate, A.; Barnes, A.; Chalishazar, V.; Cotilla-Sanchez, E.; Vaagensmith, B.; Gentle, J.; Rieger, C.; Wies, R.; et al. Resilience in an Evolving Electrical Grid. Energies 2021, 14, 694. [CrossRef]

60. Solar Thermal Electricity Global Outlook. 2016. Available online: http://www.solarpaces.org/pressroom/news/item/98-newsolar-thermal-electricity-report (accessed on 26 March 2021).

61. Ju, X.; Xu, C.; Han, X.; Zhang, H.; Wei, G.; Chen, L. Recent Advances in the PV-CSP Hybrid Solar Power Technology. In Proceedings of the AIP Conference Proceedings 1850, New Delhi, India, 27 June 2017.

62. Kuravi, S.; Trahan, J.; Goswami, D.Y. Thermal energy storage technologies and systems for concentrating solar power plants. Prog. Energy Combust. Sci. 2013, 13, 285-319. [CrossRef]

63. Sioshansi, R.; Denholm, P. The value of concentrating solar power and thermal energy storage. IEEE Trans. Sustain. Energy 2010, 3, 173-183. [CrossRef]

64. Ranjan, S.; Das, D.C.; Behera, S.; Sinha, N. Parabolic trough solar-thermal-wind-diesel isolated hybrid power system: Active power/frequency control analysis. IET Renew. Power Gener. 2018, 12, 1893-1903. [CrossRef]

65. Huang, J.; Bi, Y.; Qin, L.; Zang, G.; Li, H. Design parameters and dynamic performance analysis of a high efficient solar-ground source cooling system using parabolic trough collector. Int. J. Sustain. Energy 2020, 40, 253-282. [CrossRef]

66. Revel, G.; Leon, A.E.; Alonso, D.M.; Moiola, J.L. Dynamics and Stability Analysis of a Power System with a PMSG-Based Wind Farm Performing Ancillary Services. IEEE Trans. Circuits Syst. I Regul. Pap. 2014, 61, 2182-2193. [CrossRef]

67. Rajbongshi, R.; Saikia, L.C. Combined control of voltage and frequency of multi-area multisource system incorporating solar thermal power plant using LSA optimised classical controllers. IET Gener. Transm. Distrib. 2017, 11, 2489-2498. [CrossRef]

68. Saha, D.; Saikia, L.C. Performance of FACTS and energy storage devices in a multi area wind-hydro-thermal system employed with SFS optimized I-PDF controller. J. Renew. Sustain. Energy 2017, 9, 024103. [CrossRef]

69. Onar, O.C.; Uzunoglu, M.; Alam, M.S. Modeling, control and simulation of an autonomous wind turbine/photovoltaic/fuel cell/ultra-capacitor hybrid power system. J. Power Sources 2008, 185, 1273-1283. [CrossRef]

70. Hanif, S.; Bhattacharya, S.; Chalishazar, V.; Bhatnagar, D.; Alam, J.E.; Robertson, B.; Preziuso, D.; O’Nei, R. Storage Requirements for Grid Integration of Marine Renewable Energy_A Parametric Study. In Proceedings of the 2021 IEEE Power \& Energy Society Innovative Smart Grid Technologies Conference (ISGT), Washington, DC, USA, 16-18 February 2021; pp. 1-5.

71. García, P.; Fernández, L.M.; Torreglosa, J.P.; Jurado, F. Operation mode control of a hybrid power system based on fuel cell/battery/ultracapacitor for an electric tramway. Comput. Electr. Eng. 2013, 39, 1993-2004. [CrossRef] 
72. Gao, L.; Dougal, R.A.; Liu, S. Power enhancement of an actively controlled battery/ultracapacitor hybrid. IEEE Trans. Power Electron. 2005, 20, 236-243. [CrossRef]

73. Der Chyuan, C. Stability Improvement of a Wind/Diesel System Using an Energy Storage Unit. Bachelor's Thesis, Curtin University of Technology, Perth, WA, Australia, 2002. Available online: https:/ / dokumen.tips/documents/stability-improvement-of-awind-diesel-system-using-an-energy-storage-unit.html (accessed on 26 March 2021).

74. Senjyu, T.; Nakaji, T.; Uezato, K.; Funabashi, T. A hybrid power system using alternative energy facilities in isolated island. IEEE Trans. Energy Convers. 2005, 20, 406-414. [CrossRef]

75. Lee, D.-J.; Wang, L. Small-signal stability analysis of an autonomous hybrid renewable energy power generation/energy storage system part I: Time-domain simulations. IEEE Trans. Energy Convers. 2008, 23, 311-320. [CrossRef]

76. Sebastian, R.; Alzola, R.P. Simulation of an isolated wind diesel system with battery energy storage. Electr. Power Syst. Res. 2011, 81, 677-686. [CrossRef]

77. Chen, Y.; Lin, S.; Hong, B. Experimental Study on a Passive Fuel Cell/Battery Hybrid Power System. Energies 2013, 6, 6413-6422. [CrossRef]

78. Mohammed, O.H.; Amirat, Y.; Benbouzid, M.; Elbast, A. Optimal Design of a PV/Fuel Cell Hybrid Power System for the City of Brest in France. In Proceedings of the 2014 1st International Conference on Green Energy, ICGE, Sfax, Tunisia, 25-27 March 2014; pp. 119-123.

79. Shim, J.W.; Cho, Y.; Kim, S.; Min, S.W.; Hur, K. Synergistic Control of SMES and Battery Energy Storage for Enabling Dispatchability of Renewable Energy Sources. IEEE Trans. Appl. Supercond. 2013, 23, 5701205. [CrossRef]

80. Govardhan, N.; Santhi, R.V. Design of fuzzy PI load frequency controller for hybrid wind diesel system with SMES unit. Int. Res. J. Eng. Technol. 2015, 2, 167-174.

81. Hasanien, H.M. A set-membership affine projection algorithm-based adaptive-controlled SMES units for wind farms output power smoothing. IEEE Trans. Sustain. Energy 2014, 5, 1226-1233. [CrossRef]

82. Ali, M.H.; Wu, B.; Dougal, R.A. An Overview of SMES Applications in Power and Energy Systems. IEEE Trans. Sustain. Energy 2010, 1, 38-47. [CrossRef]

83. Ngamroo, I. Robust frequency control of wind-diesel hybrid power system using superconductivity magnetic energy storage. Int. J. Emerg. Electr. Power Syst. 2009, 10, 1553-1559.

84. Mahmood, H.; Michaelson, D.; Jiang, J. Decentralized Power Management of a PV/Battery Hybrid Unit in a Droop-Controlled Islanded Microgrid. IEEE Trans. Power Electron. 2015, 30, 7215-7229. [CrossRef]

85. Yang, L.; Tai, N.; Fan, C.; Meng, Y. Energy regulating and fluctuation stabilizing by air source heat pump and battery energy storage system in microgrid. Renew. Energy 2016, 95, 202-212. [CrossRef]

86. Tammineedi, C. Modeling Battery-Ultracapacitor Hybrid Systems for Solar. Ph.D. Thesis, The Pennsylvania State University, University Park, PA, USA, 2011.

87. Mercier, P.; Cherkaoui, R.; Oudalov, A. Optimizing a battery energy storage system for frequency control application in an isolated power system. IEEE Trans. Power Syst. 2009, 24, 1469-1477. [CrossRef]

88. Mendis, N.; Muttaqi, K.M.; Sayeef, S.; Perera, S. A control approach for voltage and frequency regulation of a wind-diesel-battery based hybrid remote area power supply system. In Proceedings of the IECON 2010-36th Annual Conference on IEEE Industrial Electronics Society, Glendale, AZ, USA, 7-10 November 2010; pp. 3054-3060.

89. Yang, H.; Chung, C.Y.; Zhao, J. Application of plug-in electric vehicles to frequency regulation based on distributed signal acquisition via limited communication. IEEE Trans. Power Syst. 2013, 28, 1017-1026. [CrossRef]

90. Liu, H.; Hu, Z.; Song, Y.; Wang, J.; Xie, X. Vehicle-to-grid control for supplementary frequency regulation considering charging demands. IEEE Trans. Power Syst. 2015, 30, 3110-3119. [CrossRef]

91. Su, W.; Chow, M.-Y. Performance evaluation of an EDA-based large-scale plug-in hybrid electric vehicle charging algorithm. IEEE Trans. Smart Grid 2012, 3, 308-315. [CrossRef]

92. Cao, Y.; Tang, S.; Li, C.; Zhang, P.; Tan, Y.; Zhang, Z.; Li, J. An optimized EV charging model considering TOU price and SOC curve. IEEE Trans. Smart Grid 2012, 3, 388-393. [CrossRef]

93. Masuta, T.; Yokoyama, A. Supplementary load frequency control by use of a number of both electric vehicles and heat pump water heaters. IEEE Trans. Smart Grid 2012, 3, 1253-1262. [CrossRef]

94. Vachirasricirikul, S.; Ngamroo, I. Robust LFC in a smart grid with wind power penetration by coordinated V2G control and frequency controller. IEEE Trans. Smart Grid 2014, 5, 371-380. [CrossRef]

95. Izadkhast, S.; Garcia-Gonzalez, P.; Frías, P. An aggregate model of plug-in electric vehicles for primary frequency control. IEEE Trans. Power Syst. 2015, 30, 1475-1482. [CrossRef]

96. Nacfaire, H. (Ed.) Wind-Diesel and Wind Autonomous Energy Systems; CRC Press: Boca Raton, FL, USA, 1989.

97. Howard, D.F.; Liang, J.; Harley, R.G. Control of Receiver Temperature and Shaft Speed in Dish-Stirling Solar Power. In Proceedings of the IEEE Energy Conversion Congress and Exposition (ECCE), Atlanta, GA, USA, 12-16 September 2010; pp. $398-405$.

98. Howard, D.F.; Harley, G. Modeling of Dish-Stirling Solar Thermal Power Generation. In Proceedings of the IEEE Power and Energy Society General Meeting, Minneapolis, MN, USA, 25-29 July 2010; pp. 1-7.

99. Mancini, T.; Heller, P.; Butler, B.; Osborn, B.; Schiel, W.; Goldberg, V.; Buck, R.; Diver, R.; Andraka, C.; Moreno, J. Dish-Stirling Systems: An Overview of Development and Status. J. Sol. Energy Eng. 2003, 125, 135-151. [CrossRef] 
100. Bansal, R.C.; Bhatti, T.S.; Kothari, D.P. Automatic reactive power control of isolated wind-diesel hybrid power systems for variable wind speed/slip. Electr. Power Compon. Syst. 2004, 32, 901-912. [CrossRef]

101. Bansal, R.C. Three-phase self-excited induction generators: An overview. IEEE Trans. Energy Convers. 2005, 20, 292-299. [CrossRef]

102. Bansal, R.C.; Bhatti, T.S.; Kothari, D.P. Bibliography on the application of induction generators in nonconventional energy systems. IEEE Trans. Energy Convers. 2003, 18, 433-439. [CrossRef]

103. Leidhold, R.; Garcia, G.; Valla, M.I. Induction generator controller based on the instantaneous reactive power theory. IEEE Trans. Energy Convers. 2002, 17, 368-373. [CrossRef]

104. Tsuda, T.; Fukami, T.; Kanamaru, Y.; Miyamoto, T. Performance analysis of the permanent-magnet induction generator under unbalanced grid voltages. IEEJ Trans. Ind. Appl. 2006, 126, 1126-1133. [CrossRef]

105. Sharma, P.; Sulkowski, W.; Hoff, B. Dynamic stability study of an isolated wind-diesel hybrid power system with wind power generation using IG, PMIG and PMSG: A comparison. Int. J. Electr. Power Energy Syst. 2013, 53, 857-866. [CrossRef]

106. Kundur, P. Control of active and reactive power. In Power System Stability and Control; McGraw-Hill: New York, NY, USA, 1993; Chapter 11; pp. 581-623.

107. Saleh, S.A.; Khan MA, S.K.; Rahman, M.A. Steady state performance analysis and modeling of direct driven interior permanentmagnet wind generators. IET Renew. Power Gener. 2011, 5, 137-147. [CrossRef]

108. Sopanen, J.; Ruuskanen, V.; Nerg, J.; Pyrhonen, J. Dynamic torque analysis of a wind turbine drive train including a direct driven permanent-magnet generator. IEEE Trans. Ind. Electron. 2011, 58, 3859-3867. [CrossRef]

109. Zhang, S.; Tseng, K.-J.; Vilathgamuwa, D.M.; Nguyen, T.D.; Wang, X.-Y. Design of a robust grid interface system for PMSG based wind turbine generators. IEEE Trans. Ind. Electron. 2011, 58, 316-328. [CrossRef]

110. Mi, Y.; Xu, Y.; Lang, Z.; Yang, X.; Ge, X.; Fu, Y.; Jin, C. The frequency-voltage stability control for isolated wind-diesel hybrid power system. Electr. Power Syst. Res. 2021, 192, 106984. [CrossRef]

111. Hingorani, N.G.; Gyugyi, L. Understanding FACTS: Concepts and Technology of Flexible AC Transmission Systems, 1st ed.; IEEE Press: Piscataway, NJ, USA, 2000.

112. Woodley, N.; Morgan, L.; Sundaram, A. Experience with an inverter-based dynamic voltage restorer. IEEE Trans. Power Deliv. 1999, 14, 1181-1186. [CrossRef]

113. Salimin, R.H.; Rahim, M.S.A. Simulation analysis of DVR performance for Voltage sag mitigation. In Proceedings of the 5th International Power Engineering and Optimization Conference, Shah Alam, Malaysia, 6-7 June 2011; pp. 261-266.

114. Wessels, C.; Hoffmann, N.; Molinas, M.; Fuchs, F.W. StatCom Control at Wind Farms with Fixed-Speed Induction Generators Under Asymmetrical Grid Faults. IEEE Trans. Ind. Electron. 2013, 60, 2864-2874. [CrossRef]

115. Vachirasricirikul, S.; Ngamroo, I.; Kaitwanidvilai, S. Coordinated SVC and AVR for robust voltage control in a hybrid wind-diesel system. Energy Convers. Manag. 2010, 51, 2383-2393. [CrossRef]

116. Sharma, P.; Bhatti, T.S. Performance Investigation of Isolated Wind-Diesel Hybrid Power Systems with WECS Having PMIG. IEEE Trans. Ind. Electron. 2013, 60, 1630-1637. [CrossRef]

117. Lu, D.D.C. An Update on Power Quality, 1st ed.; InTech: Rijeka, Croatia, 2013.

118. Hussain, I.; Das, D.C.; Sinha, N. Reactive power performance analysis of dish-stirling solar thermal diesel hybrid energy system. IET Renew. Power Gener. Syst. 2017, 11, 750-762. [CrossRef]

119. Ranjan, S.; Das, D.C.; Sinha, N.; Latif, A.; Hussain, S.M.S.; Ustun, T.S. Voltage stability assessment of isolated hybrid dish-stirling solar-thermal-diesel microgrid with STATCOM using mine blast algorithm. Electr. Power Syst. Res. 2021, 196, 107239. [CrossRef]

120. Ranjan, S.; Das, D.C.; Latif, A.; Sinha, N.; Hussain, S.M.S.; Ustun, T.S. Maiden Voltage Control Analysis of Hybrid Power System with Dynamic Voltage Restorer. IEEE Access 2021, 9, 60531-60542. [CrossRef]

121. Kurozumi, K.; Tawara, T.; Tanaka, T.; Kawagoe, Y.; Yamanaka, T.; Ikebe, H.; Shindou, K.; Miyazato, T. A hybrid system composed of a wind power and a photovoltaic system at NTTkume-jima radio relay station. In Proceedings of the Telecommunications Energy Conference, INTELEC. Twentieth International, San Francisco, CA, USA, 4-8 October 1998; pp. 785-789.

122. Bao, Y.; Li, Y. FPGA-Based Design of Grid Friendly Appliance Controller. IEEE Trans. Smart Grid 2014, 5, 924-931. [CrossRef]

123. Bhattarai, B.; Chalishazar, V.; Hammerstrom, D.; Maharjan, M. Transactive energy systems for distributed blackstart and service recovery. IET Smart Grid 2021, 4, 489-499. [CrossRef]

124. Biegel, B.; Hansen, L.H.; Andersen, P.; Stoustrup, J. Primary Control by ON/OFF Demand-Side Devices. IEEE Trans. Smart Grid 2013, 4, 2061-2071. [CrossRef]

125. Kani, S.A.P.; Nehrir, M.H. Real-time central demand response for primary frequency regulation in microgrids. In Proceedings of the 2013 IEEE PES Innovative Smart Grid Technologies Conference (ISGT), Washington, DC, USA, 24-27 February 2013 ; p. 1.

126. Pourmousavi, S.A.; Nehrir, H. Introducing dynamic demand response in the LFC model. In Proceedings of the 2015 IEEE Power \& Energy Society General Meeting, Denver, CO, USA, 26-30 July 2015; p. 1.

127. Izumi, Y.; Senjyu, T.; Yona, A. Load frequency control by using demand response with $\mathcal{H} \infty$ in isolated power systems. In Proceedings of the IEEE 15th International Conference on Harmonics and Quality of Power, Hong Kong, China, 17-20 June 2012; pp. 656-661.

128. Zhu, Q.; Yao, W.; Jiang, L.; Luo, C.; Wu, Q.H. Load frequency control with dynamic demand control for deregulated power system. In Proceedings of the 2014 IEEE PES General Meeting I Conference \& Exposition, National Harbor, MD, USA, 27-31 July 2014 ; pp. 1-5.

129. Bhuyan, M.; Das, D.C.; Ba, A.K. A Comparative Analysis of DSM Based Autonomous Hybrid Micro grid using PSO and SCA. In Proceedings of the IEEE Region 10 Symposium (TENSYMP-2019), Kolkata, India, 7-9 June 2019; pp. 765-770. 
130. Latif, A.; Paul, M.; Das, D.C.; Hussain, S.M.S.; Ustun, T.S. Price based Demand Response for Optimal Frequency Stabilization in ORC Solar Thermal based Isolated Hybrid Microgrid under Salp Swarm Technique. Electronics 2020, 9, 2209. [CrossRef]

131. Barik, A.K.; Das, D.C. Coordinated regulation of voltage and load frequency in demand response supported bio renewable cogeneration-based isolated hybrid microgrid with quasi-oppositional selfish herd optimization. Int. Trans. Electr. Energy Syst. 2020, 30, e12176. [CrossRef]

132. Latif, A.; Das, D.C.; Barik, A.K.; Ranjan, S. Illustration of demand response supported coordinated system performance evaluation of YSGA optimized dual stage PIFOD-(1 + PI) controller employed with wind-tidal-biodiesel based independent two-area interconnected microgrid system. IET Renew. Power Gener. 2020, 14, 1074-1086. [CrossRef]

133. Barik, A.K.; Tripathy, D.; Das, D.C.; Sahoo, S.C. Optimal Load-Frequency Regulation of Demand Response Supported Isolated Hybrid Microgrid Using Fuzzy PD + I Controller. Intelligent Techniques and Applications in Science and Technology, Learning and Analytics in Intelligent Systems; Springer International Publishing: Cham, Switzerland, 2020; Volume 12, pp. 798-806.

134. Barik, A.K.; Das, D.C. Proficient load-frequency regulation of demand response supported bio-renewable cogeneration based hybrid microgrids with quasi-oppositional selfish-herd optimization. IET Gener. Transm. Distrib. 2019, 13, 2889-2898. [CrossRef]

135. Barik, A.K.; Das, D.C. Optimal Load-frequency Regulation of Bio-Renewable Cogeneration based Interconnected Hybrid Microgrids with Demand Response Support. In Proceedings of the 15th IEEE India Council International Conferences (INDICON), Coimbatore, India, 16-18 December 2018.

136. Barik, A.K.; Das, D.C.; Muduli, R. Demand Response Supported Optimal Load-Frequency Regulation of Sustainable Energy based Four-Interconnected Unequal Hybrid Microgrids. In Proceedings of the IEEE International Conference on Sustainable Energy Technolo-gies and Systems (ICSETS), Bhubaneswar, India, 26 February-1 March 2019.

137. Barik, A.K.; Das, D.C.; Latif, A.; Hussain, S.M.S.; Ustun, T.S. Optimal Voltage-Frequency Regulation in Distributed Sustainable Energy-Based Hybrid Microgrids with Integrated Resource Planning. Energies 2021, 14, 2735. [CrossRef]

138. Al-Ademi, A.A.F. Load-Frequency Control of Stand-Alone Hybrid Power Systems Based on Renewable Energy Sources; Indian Institute of Technology: Delhi, India, 1996.

139. Ray, P.K.; Mohanty, S.R.; Kishor, N. Proportional-integral controller based small-signal analysis of hybrid distributed generation systems. Energy Conversat. Manag. 2011, 52, 1943-1954. [CrossRef]

140. Mohanty, S.R.; Kishor, N.; Ray, P.K. Robust H-infinite loop shaping controller based on hybrid PSO and harmonic search for frequency regulation in hybrid distributed generation system. Int. J. Electr. Power Energy Syst. 2014, 60, 302-316. [CrossRef]

141. Nandar, C.S.A. Robust PI control of smart controllable load for frequency stabilization of microgrid power system. Renew. Energy 2013, 56, 16-23. [CrossRef]

142. Mahto, T.; Mukherjee, V. Evolutionary optimization technique for comparative analysis of different classical controllers for an isolated wind-diesel hybrid power system. Swarm Evol. Comput. 2016, 26, 120-136. [CrossRef]

143. Shankar, G.; Mukherjee, V. Load frequency control of an autonomous hybrid power system by quasi-oppositional harmony search algorithm. Int. J. Electr. Power Energy Syst. 2016, 78, 715-734. [CrossRef]

144. Dash, P.; Saikia, L.C.; Sinha, N. Comparison of performances of several Cuckoo search algorithm based 2DOF controllers in AGC of multi-area thermal system. Int. J. Electr. Power Energy Syst. 2014, 55, 429-436. [CrossRef]

145. Dash, P.; Saikia, L.C.; Sinha, N. Comparison of performances of several FACTS devices using Cuckoo search algorithm optimized 2DOF controllers in multi-area AGC. Int. J. Electr. Power Energy Syst. 2015, 65, 316-324. [CrossRef]

146. Latif, A.; Hussain, S.M.S.; Das, D.C.; Ustun, T.S. Double Stage Controller Optimization for Load Frequency Stabilization in Hybrid Wind-Ocean Wave Energy Based Maritime Microgrid System. Appl. Energy 2021, 282, 116171. [CrossRef]

147. Latif, A.; Hussain, S.M.S.; Das, D.C.; Ustun, T.S. Design and Implementation of maiden dual-level Controller for Ameliorating Frequency Control in a Hybrid Microgrid. Energies 2021, 14, 2418. [CrossRef]

148. Latif, A.; Das, D.C.; Ranjan, S.; Barik, A. Comparative performance evaluation of WCA-optimised non- integer controller employed with WPG-DSPG-PHEV based isolated two-area interconnected microgrid system. IET Renew. Power Gener. 2019, 13, 725-736. [CrossRef]

149. Latif, A.; Das, D.C.; Barik, A.K.; Ranjan, S. Maiden coordinated load frequency control strategy for ST-AWEC-GEC-BDDG based independent three-area interconnected microgrid system with combined effect of diverse energy storage and DC link using BOA optimized PFOID controller. IET Renew. Power Gener. 2019, 13, 1634-2646. [CrossRef]

150. Hussain, I.; Das, D.C.; Sinha, N.; Latif, A.; Hussain, S.M.S.; Ustun, T.S. Performance Assessment of an Islanded Hybrid Power System with Different Storage Combinations Using an FPA-Tuned Two-Degree-of-Freedom (2DOF) Controller. Energies 2020, 13, 5610. [CrossRef]

151. Latif, A.; Hussain, S.M.S.; Das, D.C.; Ustun, T.S.; Iqbal, A. A Review on Fractional Order (FO) Controllers' Optimization for Load Frequency Stabilization in Power Networks. Energy Rep. 2021, 7, 4009-4021. [CrossRef]

152. Aftab, M.A.; Hussain, S.M.S.; Latif, A.; Das, D.C.; Ustun, T.S. IEC 61850 Communication Based Dual Stage Load Frequency Controller for Isolated Hybrid Microgrid. Int. J. Electr. Power Energy Syst. 2021, 130, 106909. [CrossRef]

153. Latif, A.; Hussain, S.M.S.; Das, D.C.; Ustun, T.S. Optimum synthesis of BOA optimized novel dual-stage PI-(1 + ID) controller for frequency response of microgrid. Energies 2020, 13, 3446. [CrossRef]

154. Latif, A.; Pramanik, A.; Das, D.C.; Ranjan, S.; Hussain, I. Plug in hybrid vehicle-wind-diesel autonomous hybrid power system: Frequency control using FA and CSA optimized controller. Int. J. Syst. Assur. Eng. Manag. 2018, 9, 1147-1158. [CrossRef] 
155. Ranjan, S.; Das, D.C.; Latif, A.; Sinha, N. LFC for Autonomous Hybrid Micro Grid System of 3 Unequal Renewable Areas using Mine Blast Algorithm. Int. J. Renew. Energy Res. 2018, 8, 1297-1308.

156. Barik, A.K.; Das, D.C. Active power management of isolated renewable microgrid generating power from Rooftop solar arrays, sewage waters and solid urban wastes of a smart city using Salp swarm algorithm. In Proceedings of the International Conference on Technologies for Smart-City Energy Security and Power (ICSESP), Bhubaneswar, India, 28-30 March 2018.

157. Sahu, R.K.; Panda, S.; Rout, U.K. DE optimized parallel 2-DOF PID controller for load frequency control of power system with governor dead-band nonlinearity. Int. J. Electr. Power Energy Syst. 2013, 49, 19-33. [CrossRef]

158. Sadollah, A.; Bahreininejad, A.; Eskandar, H.; Hamdi, M. Mine blast algorithm: A new population-based algorithm for solving constrained engineering optimization problems. Appl. Soft Comput. 2013, 13, 2592-2612. [CrossRef]

159. Sadollah, A.; Bahreininejad, A.; Eskandar, H.; Hamdi, M. Mine blast algorithm for optimization of truss structures with discrete variables. Comput. Struct. 2012, 102, 49-63. [CrossRef]

160. Dey, P.P.; Das, D.C.; Latif, A.; Hussain, S.M.S.; Ustun, T.S. Active Power Management of Virtual Power Plant under Penetration of Central Receiver Solar Thermal-Wind Using Butterfly Optimization Technique. Sustainability 2020, 12, 6979. [CrossRef]

161. Majumdar, S.; Mandal, K.; Chakraborty, N. Performance study of Mine Blast Algorithm for automatic voltage regulator tuning. In Proceedings of the 2014 Annual IEEE India Conference (INDICON), Pune, India, 11-13 December 2014; pp. 1-6.

162. Atawi, I.E.; Kassem, A.M.; Zaid, S.A. Modeling, Management, and Control of an Autonomous Wind/Fuel Cell Micro-Grid System. Processes 2019, 7, 85. [CrossRef] 